\title{
Strategy for Strengthening models of Cocoa Partnership in Polewali Mandar District, West Sulawesi Province
}

\author{
Bambang Setiawan', Didi Rukmana ${ }^{2}$, Mahyuddin², Darmawan Salman², Saadah², Nurjannah Hamid ${ }^{3}$ \\ ${ }^{1}$ Student of Agribusiness Study Program, Postgraduate School Hasanuddin University, Makassar 90245 Indonesia. \\ ${ }^{2}$ Lecturer of Agribusiness Study Program, Postgraduate School Hasanuddin University, Makassar 90245 Indonesia. \\ ${ }^{3}$ Lecturer of Management Study Program, Faculty Economy and Bussiness, Graduate School Hasanuddin University, Makassar 90245 Indonesia
}

Correspondence Author: Bambang Setiawan, Agribusiness Study Program, Postgraduate School Hasanuddin University, Makassar 90245 Indonesia. Email: bambangsetiawan@pasca.unhas.ac.id

Received date: 28 August 2019, Accepted date: 2 December 2019, Online date: 31 December 2019

Copyright: (C) 2019 Bambang Setiawan et al. This is an open-access article distributed under the terms of the Creative Commons Attribution License, which permits unrestricted use, distribution, and reproduction in any medium, provided the original author and source are credited.

\begin{abstract}
The agricultural partnership is a commercial collaboration between a partner enterprise and a group of partners in the agricultural enterprise sector.This study aims to analyze the strategy for strengthening the partnership model of cocoa farmers, in the district of Polewali Mandar, The analysis technique used is SWOT.The results showed that the strengths factor in this study consisted of (i) availability of land resources, (ii) availability of labor, (iii) the location of the Gardens close to the company and(iv) Main product the region. Weaknesses in this study consists of (1) farmers' capital is generally low, (2) technology is lacking, (3) poor knowledgeand(4) Pest and disease attacks. While external factor opportunities include: (1) collaboration in partnership with companies, (2) high market demand, (3) the infrastructure is available, Threats In this study price fluctuation, change of land use, and theft of cocoa fruit. From the results of the SWOT, we will formulate strategies to overcome Weaknesses or avoid the and threats one of them use the availability of land and labor to meet market demand, works with partners to provide capital and technology, and uses the potential of cocoa as a reliable product to reduce the land conversion.
\end{abstract}

Keywords: Strategy, Partnership model, Farmers.

\section{INTRODUCTION}

Cocoa is one of the main plantation crops in the regency of Polewali Mandar, in the province of West Sulawesi. The cocoa production potential in this regency is quite significant. Based on data from BPS Polewali Mandar in the figures for 2018, it has been proven that cocoa production reached 33,259.48 tonnes. With a plant area of 48,930.97 ha of all existing community plantations [1]. This shows the enormous economic potential of the population, which must be strengthened by partnership efforts.

The partnership model is a way for farmers and entrepreneurs to participate in the national economy while increasing prosperity and reducing social inequalities [2]. Consequently, the partnership is regulated by Law No. 9 of 1995, namely cooperation between small and medium-sized enterprises or large enterprises accompanied by promotion and sustainable development taking into account the principles of mutual need, strengthened and profitable [3].

Partnerships must be based on cooperative relationships that have long-term meaning.[4] There is a relationship of mutual trust. No party is harmed by a common goal of increasing profits and revenues through business development so that the link or cooperation is fairly permanent and lasting for a long time and be bound [5].

Business cooperation with the partnership system is manifested in contracts that bind the parties to the agreement. The contract contains several clauses that must be obeyed by the parties but still must consider many applied ethics and regulations [6]. The contract must consider the principle of equality and balance so that it must benefit the parties. The agreement that was carried out also did not violate the principle of fair business competition and did not lead to monopolistic practices [7].

Polewali Mandar district in sub-districk luyo , cocoa farmers have had problems in the form of difficulties in obtaining capital, farmers have simply managed their cocoa so that cocoa production is not optimal, farmers have difficulty getting production facilities and the selling price of cocoa beans is relatively low. It is expected that the partnership program managed by cocoa farmers in the Luyo sub-district with partners can bring benefits to both parties, the benefits felt for the farmers being notably the increase in agricultural production. Another expected benefit is an increase in income for cocoa farmers while for companies that obtain quality cocoa beans. 
The formulation of the problem of this research is first: how is the strategy of strengthening the partnership for cocoa producers? The goal of this research is to discover how to enhance partnership models. The benefits of this research are informational materials and considerations for driving partnerships between farmers and businesses.

\section{RESEARCH METHODS}

This research on Strategy for Strengthening models of Cocoa Partnership in Polewali Mandar District, West Sulawesi Province, was carried out in Luyo sub-district, Polewali Mandar district. This location was purposely chosen as a research location, given that this area is one of the development areas for the cocoa tree and is also one of the activities for achieving a partnership between farmers and PT. Papandayan Cocoa Industries, data collection is carried out for 2 months from September to October 2019.

This type of research used is descriptive and aims to describe the condition of farmers who work in partnership with PT Papandayan Cocoa Industries as a strategy to strengthen existing partnerships in Polewali Mandar, in order to explain the relationship/influence of indicators on the partnership strengthening strategies.

Taking of respondents is intentional (Purposive) then Determination of the number of samples using the formula Slovin [8] as following:

$=\frac{N}{1+N \cdot e^{2}}$

Where:

$\mathrm{n}$ : Number of samples

$\mathrm{N}$ : Total population $(1.144)$

e: Fault tolerance limit (error tolerance) $(10 \%)$

While the samples taken in this study were 92 people (the results have been rounded off from actual calculations) from the total population of 1,144 members. The amount is obtained from calculations:

$n=\frac{1.144}{1+1.144 .10 \%^{2}}$

$=91,96$

The primary data collection procedure is carried out in several ways, as follows:

1) Observation, namely direct representation to the object of research to look closely at the activities carried out by farmers and their partners.

2) Free structured interviews are conducted with farmers and partners to obtain detailed information on the variables to be examined.

Secondary data collection procedures are performed in several ways, as follows:

1) Documentation is a collection of documents containing data from the research site, including books, regulations, activity reports, photographs, or relevant drawings of people or institutions of relevance and information on the problem in question.

2) Library research is obtained by collecting data and documentary information that support the research to be carried out.

The function of analysis, namely SWOT Analysis Data, is to obtain information from situation analysis and to separate it into internal problems (Strengths and Weaknesses) and external issues (Opportunities and Threats). For him to describe the strategy to strengthen the partnership model for farmers using the SWOT analysis, i.e. using the strengths, weaknesses, opportunities and threats analysis (SWOT) to formulate objectives in the form of strategic actions based on external facts and internal facts to determine strategy. This method provides a simple instrument to estimate the best way to implement a strategy for various models of partnership with farmers in the future [9].

Table 1: SWOT ANALYSIS MATRIKS

\begin{tabular}{|c|c|c|c|}
\hline \multirow{2}{*}{\multicolumn{2}{|c|}{$\begin{array}{l}\text { SWOT } \\
\text { Analisys }\end{array}$}} & \multicolumn{2}{|c|}{ Analysis Internal } \\
\hline & & \multirow{2}{*}{$\begin{array}{c}\text { Sthrengths } \\
\text { S-O strategy : } \\
\text { How to build a new methodology in line with } \\
\text { the strength of the institution }\end{array}$} & \multirow{2}{*}{$\begin{array}{c}\text { Weaknesses } \\
\text { W-O strategy : } \\
\text { How to Eliminate Weaknesses to Get New } \\
\text { Opportunities }\end{array}$} \\
\hline 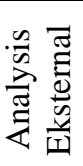 & 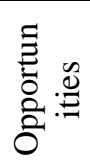 & & \\
\hline
\end{tabular}


Citation: Bambang Setiawan., 2019. Strategy for Strengthening models of Cocoa Partnership in Polewali Mandar District, West Sulawesi Province. Advances in Environmental Biology., 13(12): 72-76. DOI:10.22587/aeb.2019.13.12.13

\begin{tabular}{|c|c|c|}
\hline 苞 & $\begin{array}{c}\text { S-T strategy : } \\
\text { How to use existing internal forces to defend } \\
\text { against threats }\end{array}$ & $\begin{array}{c}\text { W-T strategy: } \\
\text { How to develop strategies to avoid weaknesses that } \\
\text { could be targeted by outside threats }\end{array}$ \\
\hline
\end{tabular}

\section{RESULT AND DISCUSSION}

In SWOT analysis, Internal factors need to be analyzed to determine the strengths and weaknesses that exist among farmers working in partnership. The analysis carried out on the internal environment as part of the development of a strategy to strengthen partnership models aims to identify the factors of strength (Strength) and weakness (Weaknesses). Based on the results of the interviews with the respondents, the elements of strength and weakness that exist in cocoa cultivation in the Luyo district are as follows:

The Strengths factor Based on the results of the interviews with the respondents, namely 1) Farmers have land available according to the development of cocoa products. This can be seen from BPS data that the area of cocoa plantation in 2018 in the mandar polewali is $49,178.11$ ha and in particular, in the cocoa plantation area of the Luyo region is 5,583.23 ha and the partnership of only 1357 ha shows great potential in the development of cocoa products in a partnership model. 2) Availability of human resources/labor According to interviews with farmers, it is said that the majority use workers who come from themselves and their own families, although some farmers use wage labor during fertilization, pruning or harvesting. BPS data shows that there were 2,387 people employed in 2019 in the plantations of the Luyo sub-district [1]. 3) Location of the farm near the factory from the results of direct observations and interviews the location of the cocoa producer in the district of Luyo, regency of Polewali Mandar, in the province of West Sulawesi is about 3 to 15 kilometers from the factory/purchasing station, which makes it easier for farmers to transport cocoa products. 4) Cocoa is a basic product for plantation products in the regency of Polewali Mandar. This is highlighted by the results of statistical data obtained from the cocoa sector in the Polewali Mandar district, which can contribute up to $20 \%$ to the economy of the district [1].

The weakness factor Based on the results of interviews with respondents, namely 1) Farmers' capital is generally low As an example based on the recognition of individual farmers who are constrained by financing problems during the purchase of production facilities such as fertilizers, medicines, etc. 2) Technology is lacking, where farmers' capacity is limited to the production and sale of dried cocoa beans to the business, as the next process of processing cocoa beans into cocoa powder is carried out by other parties that have cocoa processing technology. 3) Farmers' knowledge is generally weak. According to the results of the interviews obtained, they are only educated on average in primary school. 4) Pest and disease attacks According to the interviews, it is known that the intensity of pest/disease attacks on their plants is still quite high. In Luyo sub-district, the most common disease is CPB (cocoa moth), which often overwhelms farmers, especially when the rainy season comes.

The analysis of the external environment in the context of strengthening the partnership model of farmers in the Luyo subdistrict aims to identify the main factors of opportunity (Opportunity) and main factors of threat (Threats). Based on the results of interviews with respondents, the opportunity factors (opportunity) and the threat factors (threats) that exist in the cocoa business in Luyo district are as follows:

Opportunity factors based on the interview results are: 1) Partnership with companies As the partnership between the company and the farmers establishes a mutually beneficial relationship, the farmers benefit from supervision and training, market guarantees and bonuses while the company can respond to market demand so that, thanks to the partnership, the realization of agricultural development is realized [6]. 2) High market demand According to the results of interviews with farmers, cocoa experiences fairly high market demand. This is consistent with data from the Ministry of Agriculture indicating that cocoa is one of the main commodities with an upward trend, as evidenced by the value of Indonesian cocoa exports to the European Union in 2018 a reached 215.2 million USD, an increase of $22 \%$ compared to the 2017 period of 201.7 million USD. Not to mention the demand for cocoa beans in the country has also increased, especially in the cocoa bean processing industry for re-export. [12] 3) Available infrastructure According to the results of interviews with farmers, the road infrastructure is adequate. One example is the creation of a farm road that allows farmers to quickly get to the location of their gardens using two- or four-wheeled vehicles so that the transport of cocoa products from their gardens to the business becomes easier. Data from the Department of Agriculture and Food District. Polewali Mandar in 2019 who had built a $52 \mathrm{~km}$ agricultural road in the Luyo sub-district [11].

The threat factor According to the results of the interview, namely 1) Land transfer function, With the increase in the number of inhabitants, the demand for residential houses has also increased[13], therefore, in the district of Polewali Madar, many cocoa gardens have turned into residential land, if this continues to be left, then each year the area of cocoa plantations has decreased. Data from the Department of Agriculture and Food District. Polewali Mandar in 2019 that there has been a change of function of 4 hectares of cocoa in the sub-district of Luyo [11]. 2) Fluctuating / unstable market prices, based on the results of the interview according to which, to date, the price of Indonesian cocoa is indeed very largely determined by foreign markets. If the demand for cocoa is low from abroad, this clearly has a direct effect on the low price of cocoa. Conversely, if the demand for cocoa is high, the price of cocoa will be high, and the dollar exchange rate also influences this price change. 3) Theft of cocoa, Be aware of the results of the interview on the theft of cocoa fruit is sometimes recognized by farmers. This is due to the farmers' lack of supervision, so the cocoa is harvested by irresponsible people. Kec data. Luyo committed 5 criminal theft cases in 2019 , but since the value of the loss is less than 2.5 million, she is classified as a minor criminal offense and is therefore settled amicably. From the description above, a matrix can be produced as follows: 


\section{Table 2; SWOT MATRIKS FOR COCOA FARMERS}

\begin{tabular}{|c|c|}
\hline Strengths $(\mathbf{S})$ & Weaknesses (W) \\
\hline $\begin{array}{l}\text { 1. Availability of land resources } \\
\text { 2. Availability of labor } \\
\text { 3. The location of the Gardens close to the Company } \\
\text { 4. Main product the region }\end{array}$ & $\begin{array}{ll}\text { 1. } & \text { Farmers' capital is generally low } \\
\text { 2. } & \text { Technology is lacking } \\
\text { 3. } & \text { Poor knowledge } \\
\text { 4. } & \text { Pest and disease attacks. }\end{array}$ \\
\hline Opportunities $(\mathbf{O})$ & $\begin{array}{r}\text { Threats (T) } \\
\end{array}$ \\
\hline $\begin{array}{ll}\text { 1. } & \text { Collaboration in partnership with companies } \\
\text { 2. High market demand } \\
\text { 3. }\end{array}$ & $\begin{array}{ll}\text { 1. } & \text { Price fluctuation } \\
\text { 2. } & \text { Change of land use } \\
\text { 3. } & \text { Theft of cocoa fruit. }\end{array}$ \\
\hline
\end{tabular}

To overcome the above problems, strategies are needed to minimize the weaknesses and threats that exist by using strengths and opportunities, so that we can describe in the matrix below:

Table 3; SWOT STRATEGY MATRIX FOR FARMERS

\begin{tabular}{|c|c|c|}
\hline & Strengths (S) & Weaknesses $(W)$ \\
\hline & $\begin{array}{l}\text { 1. Availability of land resources (S1) } \\
\text { 2. Availability of labor (S2) } \\
\text { 3. The location of the Gardens close to the } \\
\text { Company (S3) } \\
\text { 4. } \text { Main product the region (S4) }\end{array}$ & $\begin{array}{ll}\text { 1. } & \text { Farmers' capital is generally low (W1) } \\
\text { 2. } & \text { Technology is lacking (W2) } \\
\text { 3. } & \text { Poor knowledge (W3) } \\
\text { 4. } & \text { Pest and disease attacks. (W4) }\end{array}$ \\
\hline Opportunities (O) & \begin{tabular}{|c|} 
Strategy SO \\
\end{tabular} & Strategy WO \\
\hline 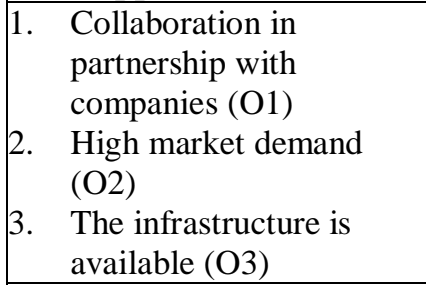 & $\begin{array}{l}\text { Increase cocoa production by strengthening } \\
\text { partnerships that can harness the potential of } \\
\text { land and human resources and infrastructure } \\
\text { to meet market demand }(\mathrm{S} 1, \mathrm{~S} 2, \mathrm{~S} 3, \mathrm{~S} 4, \mathrm{O} 1 \text {, } \\
\mathrm{O} 2, \mathrm{O} 3)\end{array}$ & $\begin{array}{l}\text { Company cooperation is expected to help } \\
\text { farmers access capital, technology and } \\
\text { science to control pest and disease attacks } \\
\text { (W1, W2,W3,W4,O1,O2,O3) }\end{array}$ \\
\hline Threats $(\mathbf{T})$ & Strategy ST & Strategy WT \\
\hline $\begin{array}{ll}\text { 1. } & \text { Price fluctuation (T1) } \\
\text { 2. } & \text { Change of land use (T2) } \\
\text { 3. } & \text { Theft of cocoa fruit (T3) }\end{array}$ & $\begin{array}{l}\text { 1. Apply agricultural diversification } \\
\text { models }(\mathrm{S} 1, \mathrm{~S} 2, \mathrm{~T} 1) \\
\text { 2. } \\
\text { Conduct cooperative relationships with } \\
\text { government institutions to minimize the } \\
\text { conversion of the cocoa land function } \\
\text { as well as cooperation with the security } \\
\text { forces in the fight against cocoa fruit } \\
\text { theft }(\mathrm{S} 2, \mathrm{~S} 4, \mathrm{~T} 2)\end{array}$ & $\begin{array}{l}\text { 1. Cocoa producers are asked to harvest } \\
\text { often to avoid losses due to pests and } \\
\text { diseases and theft of cocoa pods } \\
\text { (W3,W4,T3). }\end{array}$ \\
\hline
\end{tabular}

\section{CONCLUSION}

From the results of the SWOT, we will formulate strategies to overcome Weaknesses or avoid and threats one of them use the availability of land and labor to meet market demand, works with partners to provide capital and technology, and uses the potential of cocoa as a reliable product to reduce the land conversion.

\section{REFERENCES}

[1] Indonesian Bureau of Statistics (IBS). 2018. Kabupaten Polewali Mandar Dalam Angka

[2] Mursalat. A, 2017. Strategi Penerapan Pola Kemitraan Transfer Teknologi dalam Agribisnis Kakao. (Studi Kasus Pada PT. Mars Symbioscience Indonesia). Thesis Magister Agribusiness. Hasanuddin University. Makassar

[3] Pratiwi, T. 2014. Evaluasi Kemitraan Antara PT Pagottan Dengan Petani Tebu di Kabupaten Madiun. Skripsi. Bogor Agricultural Institute. Bogor.

[4] Parrangan, 2014. Pengaruh Modal Sosial dan Strategi Kemitraan Terhadap Kinerja Rantai Pasok Hortikultura Sayuran. Tesis. Hasanuddin University, Makassar

[5] Sirajuddin, S.N., Hastang, V.N. Lestari, Rosmawaty. 2019. Livestock ecology research on institution and traditional sharing systems in cattle farms. Eurasia J Biosci. 13 : 239-244 
[6] Sirajuddin, S. N., Nurlaelah, S., Amrawaty, A., Amrullah, T., Rohani, S. and Saleh, I. M. 2017. Relationship Between Farmers Characteristic and Income from Beef Cattle with The Traditional Profit-Sharing. American-eurasian journal of sustainable Agriculture 11(5):29-34.

[7] Sirajuddin, S. N., Mappangaja, A. R., Darma, R., \& Sudirman, I. (2015). Value added analysis of beef cattle supply chain actors micro-scale community farm based. American-Eurasian Journal of Sustainable Agriculture, 9(7), 7-12.

[8] Riduwan, 2005. Metode dan Teknik Penyusunan Tesis. Bandung: CV Alfa Beta. Jakarta

[9] Rangkuti, Freddy, 2009. Analisis SWOT Teknik Membedah Kasus Bisnis, Gramedia Pustaka Utama Jakarta

[10] Yunus, Muh, et al. "Analysis of land use changes in the Coastal Pangkep." American-Eurasian Journal of Sustainable Agriculture, vol. 9, no. 8, 2015, p. 8+. Gale Academic Onefile, Accessed 10 Jan. 2020.

[11] Dinas Pertanian dan Pangan Kabupaten Polewali Mandar 2019. Data Base Pertanian Terintegrasi.

[12] https://www.gatra.com/detail/news/419876/Economy/ekspor-kakao-meningkat-indonesia-terus-perluas-pasar-uni-eropa

[13] Sirajuddin, S. N., Siregar, A. R., Nurlaelah, S., Lestari, V. S., \& Tenrisanna, V. (2017). The limitations and benefits of partnership sharing system of Corporated Cattle Market (CCM). American-Eurasian Journal of Sustainable Agriculture, 11(1), 11-15. 